\title{
JUS SEMANGKA MENURUNKAN NEUTROFIL TIKUS JANTAN GALUR WISTAR YANG TERPAPAR ASAP ROKOK
}

\author{
Rizky Prihandari' ${ }^{1}$, Lailatul Muniroh ${ }^{2}$ \\ ${ }^{1}$ Prodi S1 Ilmu Kesehatan Masyarakat, Minat Gizi Fakultas Kesehatan Masyarakat Universitas Airlangga \\ ${ }^{2}$ Departemen Gizi Kesehatan, Fakultas Kesehatan Masyarakat Universitas Airlangga, Surabaya \\ Email: rizky.prihandari24@gmail.com
}

\begin{abstract}
ABSTRAK
Asap rokok mengandung radikal bebas yang mengganggu sistem pernapasan. Jus semangka "Sugar Baby" mengandung likopen sebagai anti inflamasi. Penelitian ini bertujuan untuk menganalisis pengaruh jus semangka sebagai anti inflamasi pada neutrofil tikus jantan galur wistar yang terpapar asap rokok. Penelitian ini merupakan penelitian eksperimental laboratorium dengan desain tes pra dan pasca-grup kontrol. Sampel terdiri dari 24 tikus jantan galur wistar dengan berat \pm 150-230 gram dan usia 3 bulan yang dibagi ke dalam 4 kelompok. Kelompok kontrol diberikan perlakuan berupa akuades sebagai plasebo dan ketiga kelompok perlakuan diberikan jus semangka dengan kuantitas bertingkat $(1,5$ $\mathrm{ml}, 2,5 \mathrm{ml}$, dan 3,5 ml). Setiap kelompok dipapar dengan asap rokok dari 2 batang rokok perhari selama dua minggu. Selanjutnya selama satu minggu dipapar dan diberi perlakuan. Perhitungan neutrofil dari hapusan darah tepi diamati dengan cara manual. Data perhitungan neutrofil dianalisis statistik menggunakan Anova Mixed Design dan dilanjutkan dengan One Way Anova. Hasil dari penelitian menunjukkan peningkatan yang bermakna pada pengamatan kedua, kelompok kontrol $(p=0,002)$ dan kelompok perlakuan $(p=0,000)$. Penurunan yang bermakna ditunjukkan oleh kelompok perlakuan pada pengamatan ketiga $(\mathrm{p}=0,000)$. Nilai signifikan antara kelompok $\mathrm{p}=0,017$. Terdapat perbedaan yang bermakna antara kelompok kontrol dan ketiga kelompok perlakuan namun tidak terdapat perbedaan yang bermakna antar masing-masing kelompok perlakuan. Disimpulkan bahwa terdapat penurunan neutrofil pada tikus jantan galur wistar yang diberikan jus semangka sebanyak 1,5 ml, 2,5 ml, dan 3,5 ml selama keradangan. Pemberian jus semangka $3,5 \mathrm{ml}$ menunjukkan hasil yang lebih baik sebagai anti inflamasi.
\end{abstract}

Kata kunci: asap rokok, jus semangka, neutrofil

\section{ABSTRACT}

Cigarette smoke contains many hazardous substances and free radical which affect respiratory system. Watermelon "Sugar Baby" juice contain lycopene as antiinflammation. The aim of this research was to analyze the effect of watermelon as antiinflammation toward neutrophils count in wistar strain male rats exposed by cigarette smoke. This study was an experimental laboratory research with pre and post test control group design. Sample consisted of 24 wistar strain male rats with $\pm 150-230$ grams weight and 3 months old which were divided into four groups. Control group was given placebo (aquadest) and treatment groups were given watermelon juice with terraced quantity (1.5 $\mathrm{ml}, 2.5 \mathrm{ml}$, and $3.5 \mathrm{ml}$ ). Every group was given two sticks of cigarette smoked per day during two weeks then smoked with treatment during one week. Neutrophil from peripheral smear was observed by manual method and statistically analyzed using Anova Mixed Design and continued with One Way Anova. The result showed significant increased of neutrophil at second observation on control group $(p=0.002)$ and treatment groups $(p=0.000)$. Significance decreased also found in the treatment groups's at third observation $p=0.000$. Significant between each group $p=0.017$. There was significant different between control and treatment groups but there was no significant different between each treatment groups. This study concluded that there was decreased of neutrophil in wistar strain male rats which were given watermelon juice $1.5 \mathrm{ml}, 2.5 \mathrm{ml}$, and $3.5 \mathrm{ml}$ during inflammation. $3.5 \mathrm{ml}$ watermelon juice which were given showed better result as antiinflammation.

Keywords: cigarette smoke, watermelon juice, neutrophil

\section{PENDAHULUAN}

Jumlah perokok di negara maju maupun negara berkembang sangat banyak. Hal ini dapat dilihat dari data World Health Organization-
Framework Convention on Tobacco Control (WHO-FCTC) tahun 2015 yang menyatakan bahwa Indonesia merupakan salah satu negara yang memiliki jumlah perokok tertinggi di dunia. 
Jumlah perokok laki-laki berusia lebih dari 15 tahun mencapai 50,6 juta jiwa dan menduduki peringkat ketiga di dunia. Sementara itu, negara maju seperti Amerika Serikat memiliki jumlah perokok sebanyak 21,6 jua jiwa dan menduduki peringkat keenam jumlah perokok terbesar di dunia (Eriksen, dkk., 2015)

Perilaku merokok di Indonesia menunjukkan kecenderungan peningkatan dari tahun 2007 sebesar 34,2\% hingga pada tahun 2013 sebesar $36,3 \%$. Perokok di Indonesia pada tahun 2013 terdiri dari $64,9 \%$ penduduk laki-laki dan 2,1\% penduduk perempuan. (Balitbangkes RI, 2013).

Perokok pasif berjumlah lebih banyak dibandingkan dengan perokok aktif di Indonesia. Jumlah perokok aktif di Indonesia sebesar 34,5\% sedangkan jumlah perokok pasif dikategorikan berdasar tempat terpaparnya, yakni di dalam rumah sebesar 78,4\% dan di kantor sebesar 51,3\%. Terdapat dua jenis asap rokok, yakni asap yang berasal dari ujung rokok yang dibakar (sidestream cigarette smoke) dan asap yang dihisap pada pangkal rokok (mainstream cigarette smoke). Perokok pasif cenderung akan menghirup asap rokok jenis sidestream cigarette smoke yang berada di lingkungan sekitarnya dan perokok aktif akan cenderung menghirup asap berjenis mainstream cigarette smoke pada pangkal rokok yang dihisap. Asap yang berasal dari kegiatan merokok ini akan berdampak buruk bagi lingkungan dan kesehatan manusia, tidak hanya bagi perokok aktif tetapi juga bagi perokok pasif. (Balitbangkes RI, 2012).

Asap rokok merupakan suatu gas yang mengandung berbagai macam zat berbahaya dan radikal bebas. Pada percobaan pemaparan dua batang rokok per hari pada tikus jantan galur wistar selama dua minggu dapat menunjukkan respons inflamasi dengan penanda meningkatnya neutrofil pada darah tepi (Prihandari, 2016).

Dampak kesehatan bagi perokok aktif maupun pasif khususnya adalah terjadinya kerusakan pada organ dan saluran pernapasan. Pada awalnya kerusakan organ dan saluran pernapasan yang terpapar asap rokok akan mengalami keradangan atau inflamasi. Inflamasi ini yang akan menimbulkan suatu reaksi respons inflamasi dalam tubuh terhadap organ yang meradang. Respons inflamasi ini mengakibatkan terjadinya leukositosis atau peningkatan jumlah sel darah putih dan salah satunya juga akan meningkatkan sel darah putih dengan jenis neutrofil yang berperan dalam menurunkan peradangan pada tubuh atau yang disebut dengan neutrofilia. Tubuh akan memproduksi lebih banyak sel darah putih atau leukosit untuk meningkatkan kekebalan tubuh dalam mempertahankan kondisi tubuh tersebut (Dorland, 2002).

Peningkatan produksi sel darah putih akan menyebabkan neutrofil pada darah tepi meningkat hingga melebihi batas normal nilai persentase neutrofil. Nilai normal persentase neutrofil pada manusia yakni berkisar antara 50 hingga $70 \%$ sedangkan pada tikus jantan galur wistar sebesar 4,5\% hingga 23,5\%. (Lestariningrum, dkk., 2012). Neutrofil merupakan salah satu jenis sel darah putih penanda inflamasi atau peradangan. Neutrofil akan bekerja ketika terdapat sinyal dari hormon sitokin yang menunjukkan lokasi terjadinya inflamasi dalam tubuh sehingga terjadi peningkatan jumlah neutrofil pada darah tepi (Hoffbrand, dkk., 2005).

Respon inflamasi dapat diturunkan oleh likopen. Likopen merupakan zat non gizi yang terdapat dalam daging semangka yang berwarna kemerahan. Likopen menurunkan respon inflamasi dengan cara menurunkan aktivitas produksi molekul pro inflamasi sehingga menghambat terjadinya inflamasi. Hal ini menunjukkan bahwa buah semangka bermanfaat untuk mengurangi efek inflamasi pada organ dan saluran pernapasan akibat paparan asap rokok (Rosalina, 2013).

Semangka jenis Sugar Baby merupakan semangka yang memiliki daging buah berwarna kemerahan yang mengandung likopen. Ukuran dalam $100 \mathrm{ml}$ jus semangka jenis Sugar Baby mengandung 4,53 $\pm 0,06 \mathrm{mg}$ likopen (Naz, dkk., 2013). Penelitian Devaraj, dkk. (2008) pada dosis likopen $6,5 \mathrm{mg}$ dapat menurunkan reaksi stress oksidatif.

Penelitian mengenai pengaruh pemaparan asap rokok terhadap kadar leukosit telah dilakukan oleh Suryani (2011), namun penelitian tersebut tidak secara khusus melihat pengaruh pemaparan terhadap neutrofil. Sementara itu, penelitian mengenai pengaruh pemberian vitamin $\mathrm{E}$ terhadap neutrofil telah dilakukan oleh Yuniharilmy (2011). Belum terdapat penelitian yang melihat 
pengaruh pemberian jus semangka terhadap kadar neutrofil sebagai penanda inflamasi pada perokok. Oleh karena itu, penelitian ini bertujuan untuk menganalisis penurunan neutrofil pada tikus jantan galur wistar yang terpapar asap rokok dengan pemberian jus semangka.

\section{METODE}

Penelitian ini merupakan jenis penelitian eksperimental murni dengan menggunakan 28 tikus jantan galur wistar dengan kriteria yaitu berumur 3 bulan, memiliki berat badan \pm 150 hingga 300 gram, memiliki nafsu makan baik, tidak cacat fisik, dan bergerak aktif yang dibagi menjadi 4 kelompok, yaitu kelompok kontrol dan tiga kelompok perlakuan. Perbedaan keempat kelompok berada pada jenis perlakuan yang diberikan. Pemberian plasebo berupa akuades pada kelompok kontrol dan pemberian jus semangka sebanyak 1,5 ml, 2,5 ml, dan 3,5 ml pada kelompok perlakuan 1 , perlakuan 2 , dan perlakuan 3 secara berturut-turut.

Tahap awal penelitian dilakukan pengelompokan hewan coba dengan cara melakukan penimbangan berat badan dan penandaan hewan coba terlebih dahulu. Rumus yang digunakan untuk memenuhi sampel yang digunakan dalam penelitian menurut Federer (1967), yaitu:

$$
(\mathrm{t}-1)(\mathrm{r}-1)>15
$$

Tahap selanjutnya dilakukan pengelompokan menggunakan metode randomized block design untuk membagi hewan coba ke dalam 4 kelompok secara homogen. Tiap kelompok berisi 7 ekor hewan coba termasuk 1 ekor sebagai cadangan apabila hewan coba drop out selama penelitian baik karena mati ataupun karena timbul efek samping. Terdapat empat hewan coba drop out dikarenakan mati pada minggu pertama dan minggu kedua penelitian sehingga total hewan coba dalam penelitian ini sebanyak 24 ekor.

Tabel 1 menggambarkan bahwa pengamatan pertama dalam penelitian yang dilakukan setelah tahap adaptasi pada seluruh hewan coba di tiap kelompok pada minggu pertama dengan cara pemberian makan dan minum ad libitum (pemberian seperti biasa dengan jumlah yang sama). Pemberian makan berupa pakan dengan komposisi jagung, dedak, tepung ikan, bungkil kedelai, bungkil kelapa, tepung daging dan tulang, pecahan gandum, bungkil kacang tanah, canola, tepung daun, vitamin, kalsium, fosfat, dan trace mineral. Akhir minggu pertama penelitian dilakukan pengambilan darah tepi dengan cara melukai sedikit bagian ekor hewan coba menggunakan gunting bedah dan mengeluarkan \pm 1 tetes darah hewan coba yang diletakkan di atas object glass, lalu dilakukan pembuatan hapusan pada darah tersebut. Hapusan yang telah dibuat dibiarkan dulu kering pada suhu ruang selama 5 menit untuk kemudian dilakukan proses fiksasi yang berfungsi untuk mempertahankan morfologi sel pada hapusan darah tepi dengan cara mencelupkan bagian hapusan ke dalam metanol \pm selama 5 menit, kemudian pada hapusan dibiarkan kering. Selanjutnya dilakukan pewarnaan hapusan dengan menggunakan cat giemsa. Hapusan darah tepi yang telah diwarnai menggunakan giemsa kemudian diamati secara manual menggunakan mikroskop dengan pembesaran 1000 kali pada sepertiga bagian ekor hapusan untuk melakukan penghitungan jenis leukosit pada daerah yang optimal untuk dilakukan pembacaan dikarenakan pada bagian tersebut sel tidak menumpuk. Pembacaan hapusan darah tepi akan memberikan hasil berupa nilai persentase neutrofil tiap hewan coba. Persentase neutrofil hewan coba didapatkan dengan menggunakan rumus sebagai berikut:

$$
\frac{\text { Jumlah neutrofil dalam } 100 \text { leukosit }}{100 \text { leukosit }}: \times 100 \%
$$

Selanjutnya, dilakukan perhitungan rerata persentase neutrofil tiap kelompok hewan coba. Pengamatan ini bertujuan untuk memperoleh gambaran persentase neutrofil hewan coba dalam kondisi normal.

Tahap selanjutnya yaitu pemaparan asap rokok selama dua minggu kepada tiap kelompok hewan coba secara sidestream cigarette smoke dengan menggunakan dua batang rokok kretek tanpa filter setiap hari yang dipaparkan pada pagi hari pukul 07.00 WIB dan sore hari pukul 14.30 WIB setiap harinya. Pada akhir minggu ketiga penelitian dilakukan pengambilan darah tepi seluruh hewan 
Tabel 1. Pengamatan pada Penelitian

\begin{tabular}{|c|c|c|c|}
\hline Kelompok & $\begin{array}{c}\text { Pengamatan } 1 \\
\text { (Adaptasi } 1 \text { minggu) }\end{array}$ & $\begin{array}{c}\text { Pengamatan } 2 \\
\text { (Pemaparan asap rokok } 2 \\
\text { minggu) }\end{array}$ & $\begin{array}{c}\text { Pengamatan } 3 \\
\text { (Pemaparan dan permberian } \\
\text { perlakuan } 1 \text { minggu) }\end{array}$ \\
\hline Kontrol & & Dilakukan setelah pemaparan & Perlakuan: akuades 2,5 ml \\
\hline Perlakuan 1 & Dilakukan setelah adaptasi & menggunakan 2 batang rokok & Perlakuan: jus semangka $1,5 \mathrm{ml}$ \\
\hline Perlakuan 2 & makan dan minum ad libitum & Pemaparan 1: $07.00 \mathrm{WIB}$ & Perlakuan: jus semangka $2,5 \mathrm{ml}$ \\
\hline Perlakuan 3 & & Pemaparan 2: 14.30 WIB & Perlakuan: jus semangka $3,5 \mathrm{ml}$ \\
\hline
\end{tabular}

coba kembali \pm 30 menit setelah selesai pemaparan batang rokok pada sore hari untuk kemudian dilakukan pengamatan hitung neutrofil secara manual sehingga didapatkan rerata persentase neutrofil pada pengamatan kedua. Analisis pada pengamatan kedua ini bertujuan untuk melihat perubahan persentase neutrofil hewan coba setelah dilakukan pemaparan asap rokok.

Tahap selanjutnya yaitu melakukan pemaparan asap rokok seperti pada minggu sebelumnya dengan penambahan pemberian perlakuan pada setiap hewan coba sesuai dengan kelompoknya, seperti pemberian akuades sebagai plasebo pada kelompok kontrol sebanyak 2,5 ml, pemberian jus semangka masing-masing sebanyak $1,5 \mathrm{ml}$, 2,5 $\mathrm{ml}$, dan 3,5 $\mathrm{ml}$ untuk kelompok perlakuan 1, 2, dan 3 melalui sonde pada hewan coba. Jus semangka yang diberikan menggunakan semangka jenis Sugar Baby yang diperoleh dengan cara menghaluskan beberapa potong semangka menggunakan mixer genggam tanpa menambahkan air ke dalam campuran jus semangka sehingga didapatkan sari semangka murni. Pemberian perlakuan dilakukan kepada seluruh hewan coba \pm 30 menit setelah pemaparan asap rokok pada sore hari. Akhir minggu keempat penelitian dilakukan pengambilan darah tepi seluruh hewan coba kembali \pm 30 menit setelah pemberian perlakuan. Pengamatan ini merupakan pengamatan ketiga dalam penelitian. Pengamatan ketiga ini bertujuan untuk melihat dampak pemberian perlakuan kepada tiap kelompok hewan coba dengan cara membandingkan hasil antar kelompok maupun dengan hasil pada pengamatan sebelumnya.

Tahap terakhir dalam penelitian yaitu melakukan euthanasia atau pemusnahan hewan coba setelah penelitian untuk mencegah kesakitan pada hewan coba yang diakibatkan oleh pemberian paparan maupun perlakuan selama penelitian.
Pemusnahan hewan coba dilakukan dengan cara melakukan penyuntikan pada daerah paha kaki belakang tikus menggunakan larutan ketamin sebanyak $0,5 \mathrm{ml}$ per hewan coba. Selanjutnya, setelah dilakukan pemusnahan maka pada seluruh hewan coba dikumpulkan untuk dilakukan pemusnahan fisik hewan coba untuk menghindari pencemaran lingkungan yang dapat membahayakan kesehatan manusia yang berada di sekitarnya.

Variabel penelitian ini meliputi persentase neutrofil hewan coba pada tiap pengamatan dan jenis serta kuantitas pemberian perlakuan. Pengamatan dilakukan sebanyak 3 kali, yaitu satu minggu setelah adaptasi, 2 minggu setelah pemaparan asap rokok, dan 1 minggu setelah pemaparan serta pemberian perlakuan. Perhitungan rerata neutrofil tiap kelompok pada setiap pengamatan berdasarkan data persentase neutrofil pada tiap hewan coba yang diperoleh melalui pembacaan hitung neutrofil oleh 3 orang analis.

Alat dan bahan yang digunakan dalam penelitian ini dibagi menjadi tujuh tahapan. Dua tahapan persiapan, tiga tahapan pemaparan dan pemberian perlakuan serta dua tahapan pasca perlakuan. Alat dan bahan yang dibutuhkan dalam penelitian pada tahap awal saat penandaan dan pengelompokan hewan coba yaitu 4 kandang hewan coba, kuas, dan cat rambut. Pada tahap pembuatan jus semangka, alat dan bahan yang digunakan adalah mixer genggam, semangka Sugar Baby, pisau, dan gelas sebagai wadah.

Pada tahap pemaparan asap rokok, alat dan bahan yang digunakan adalah spuit $60 \mathrm{ml}$, kotak kaca hewan coba (ukuran $50 \times 42 \times 24 \mathrm{~cm}$ ), rokok kretek tanpa filter, selang khusus untuk pemaparan asap rokok, dan korek api. Alat dan bahan yang digunakan selanjutnya yakni pada tahapan pemberian perlakuan yaitu spuit $5 \mathrm{ml}$, jarum khusus modifikasi untuk sonde, akuades, 
dan jus semangka. Pada tahap pengambilan darah tepi hewan coba, yaitu alkohol $70 \%$, pisau bedah, methyl alcohol, kaca objek, dan pensil.

Pewarnaan giemsa pada slide hapusan darah tepi yang telah difiksasi menggunakan alat dan bahan yaitu rak pengecatan, methyl alcohol, buffer, cat giemsa, air, pipet pasteur, dan tabung reaksi. Pada tahapan akhir yakni perhitungan neutrofil menggunakan alat dan bahan oil emersi, counter, dan mikroskop cahaya "Boeco BM-180".

Data persentase neutrofil yang telah diperoleh selanjutnya diolah secara analitik menggunakan metode Anova Mixed Design dan One Way Anova yang dilanjutkan uji Post hoc metode LSD dengan nilai signifikansi $\alpha=5 \%$ untuk mengetahui perbedaan pada hasil One Way Anova. Hasil analisis disajikan dalam bentuk tabel, grafik, dan narasi. Hasil penelitian juga disajikan dalam bentuk gambaran mikroskopis morfologi neutrofil pada tiap kelompok.

Penelitian ini telah mendapatkan persetujuan etik oleh komisi etik penelitian kesehatan Fakultas Kesehatan Masyarakat Universitas Airlangga dengan nomor etik 468-KEPK.

\section{HASIL DAN PEMBAHASAN}

Penelitian menggunakan hewan coba 24 tikus jantan galur wistar dengan rerata berat badan hewan coba pada kelompok kontrol sebesar 185 gram, kelompok perlakuan 1 sebesar 187,5 gram, kelompok perlakuan 2 sebesar 185,7 gram, dan kelompok perlakuan 3 sebesar 188,8 gram. Nilai normal neutrofil tikus jantan 4,5\% hingga 23,5\%.

Tabel 2. Rerata Neutrofil Tiap Kelompok pada Tiap Pengamatan (\%)

\begin{tabular}{lccc}
\hline Kelompok & $\begin{array}{c}\text { Rerata } \\
\text { Neutrofil } \\
\text { Pengamatan }\end{array}$ & $\begin{array}{c}\text { Rerata } \\
\text { Neutrofil } \\
\text { Pengamatan }\end{array}$ & $\begin{array}{c}\text { Rerata } \\
\text { Neutrofil } \\
\text { Pengamatan }\end{array}$ \\
\hline Kontrol & 16,2 & 26,3 & $\mathbf{3}$ \\
Perlakuan 1 & 17,5 & 30,0 & 29,3 \\
Perlakuan 2 & 13,3 & 27,8 & 19,2 \\
Perlakuan 3 & 15,2 & 31,2 & 19,2 \\
Nilai normal neutrofil tikus jantan: 4,5-23,5 & \\
\hline
\end{tabular}

Pengamatan pertama menunjukkan persentase neutrofil seluruh kelompok hewan coba berada pada rentang normal. Rerata neutrofil pada pengamatan pertama menunjukkan hasil yang sama yaitu berada pada rentang 13 hingga 17 persen. Hal ini sesuai dengan teori menurut Balkaya dan Ramsley dalam Lestariningrum, dkk. (2012) yang menyebutkan bahwa persentase neutrofil normal tikus jantan berkisar antara 4,5-23,5\%.

Pada pengamatan kedua terjadi peningkatan persentase neutrofil seluruh kelompok hewan coba hingga berada di atas rentang normal. Rerata neutrofil pengamatan kedua yang dilakukan pada seluruh kelompok hewan coba setelah pemaparan asap rokok selama dua minggu menggunakan dua batang rokok kretek tanpa filter per hari untuk tiap kelompok menunjukkan peningkatan yang bermakna. Hal ini sesuai dengan teori yang menunjukkan bahwa pemaparan menggunakan asap rokok berbahaya karena banyak mengandung bahan-bahan beracun seperti tar, nikotin, dan karbon monoksida yang merupakan racun utama dalam rokok. Dampak yang diakibatkan oleh ketiga racun utama ini yaitu terjadinya gangguan pada saluran dan organ pernapasan sehingga akan menimbulkan suatu respons inflamasi atau keradangan pada sistem pernapasan. Tar yang terkandung pada asap rokok akan mengakibatkan timbulnya plak pada sistem pernapasan (Larson, 2003).

Peningkatan pada pengamatan kedua yang berkisar antara 26-32\% menunjukkan bahwa pada seluruh kelompok hewan coba memiliki hasil neutrofil melebihi nilai normal pada tikus jantan. Hal ini sesuai dengan teori yang menyebutkan bahwa terjadinya peningkatan pada neutrofil dari darah tepi merupakan penanda terjadinya stres oksidatif diakibatkan oleh adanya radikal bebas yang terkandung dalam asap rokok yakni Nitric Oxide (NO) yang akan bereaksi di dalam tubuh sehingga meningkatkan aktivitas pembentukan sel inflamasi atau keradangan (Stavridis, 2008).

Peningkatan neutrofil pada pengamatan kedua sesuai dengan teori yang menunjukkan bahwa peningkatan pelepasan neutrofil dari sumsum tulang menuju daerah atau lokasi yang mengalami inflamasi sehingga selama 5 jam pertama akan dijumpai peningkatan neutrofil dalam darah tepi. Pelepasan neutrofil pada jaringan yang mengalami inflamasi merupakan suatu respons sel di mana menurut fungsinya, neutrofil di dalam tubuh akan 
melakukan fagositosis, kemotaksis, dan membunuh serta mencerna agen penyebab inflamasi atau benda asing yang berada di dalam tubuh (Hoffbrand, dkk., 2005).

Nikotin yang terkandung dalam asap rokok dapat menurunkan fungsi neutrofil sebagai fagositosis, kemotaksis, maupun fungsinya untuk mencerna dan membunuh benda asing yang terdapat pada tubuh. Hal ini akan mengakibatkan pelepasan neutrofil dari sumsum tulang menjadi lebih banyak lagi dan akan menyebabkan ketahanan tubuh menurun sehingga cenderung lebih mudah terjadi infeksi pada sistem pernapasan dengan kondisi tubuh yang memiliki sel neutrofil dengan fungsi yang menurun (Healey, 2011).

Pada pengamatan ketiga terdapat penurunan persentase neutrofil oleh ketiga kelompok perlakuan hingga berada pada rentang normal namun pada kelompok kontrol terjadi peningkatan persentase neutrofil dibandingkan pengamatan sebelumnya. Rerata neutrofil pada pengamatan ketiga menunjukkan hasil penurunan neutrofil yang bermakna pada ketiga kelompok perlakuan yang diberikan jus semangka sebanyak 1,5 ml, 2,5 $\mathrm{ml}$ dan 3,5 $\mathrm{ml}$ secara berturut-turut. Penurunan neutrofil pada ketiga kelompok perlakuan berbanding terbalik dengan peningkatan yang terjadi pada kelompok kontrol namun berdasar hasil analisis statistik pada kelompok kontrol menunjukkan peningkatan yang tidak bermakna.

Penurunan neutrofil pada ketiga kelompok perlakuan menunjukkan hasil rentang neutrofil hingga berada pada rentang normal neutrofil bagi tikus jantan. Hal ini sesuai dengan penelitian sebelumnya oleh Devaraj, dkk. (2008) yang memberikan hasil bahwa pada 2,5 $\mathrm{ml}$ jus semangka yang merupakan hasil konversi dari dosis likopen $6,5 \mathrm{mg}$ sebagai dosis yang dapat menurunkan reaksi stres oksidatif dalam tubuh. Penurunan yang paling banyak terdapat pada kelompok perlakuan 3 dengan pemberian $3,5 \mathrm{ml}$ jus semangka per hari selama satu minggu yaitu sebesar 12 persen. Hal ini sesuai dengan penelitian sebelumnya oleh Naz, dkk. (2013) yang menunjukkan hasil likopen yang diperoleh dalam jus semangka jenis Sugar Baby sebanyak $100 \mathrm{ml}$ yaitu sebesar 4,53 $\pm 0,05 \mathrm{mg}$ sehingga penambahan kuantitas pada jus semangka
Tabel 3. Perbandingan Tiap Kelompok Antar Pengamatan

\begin{tabular}{lccc}
\hline Kelompok & Pengamatan & $\begin{array}{c}\text { Mean } \\
\text { Difference }\end{array}$ & Sig. \\
\hline \multirow{2}{*}{ Kontrol } & 1 dan 2 & $-10,2$ & 0,002 \\
& 2 dan 3 & -3 & 0,087 \\
\hline \multirow{2}{*}{ Perlakuan 1 } & 1 dan 2 & $-12,5$ & 0,000 \\
& 2 dan 3 & 8,8 & 0,000 \\
\hline \multirow{2}{*}{ Perlakuan 2 } & 1 dan 2 & $-14,5$ & 0,000 \\
\multirow{2}{*}{ Perlakuan 3 } & 2 dan 3 & 8,1 & 0,000 \\
\hline
\end{tabular}

dalam penelitian akan menambah kadar likopen yang diberikan pada hewan coba juga.

Hasil pada Analisis Anova Mixed Design yang ditunjukkan pada Tabel 3 menggambarkan adanya interaksi antara waktu pengamatan (pengamatan 1, 2, dan 3) dengan jenis kelompok hewan coba (kelompok kontrol, perlakuan 1, perlakuan 2, dan perlakuan 3). Pada kelompok kontrol terdapat peningkatan persentase neutrofil yang bermakna (Gambar 1) sebesar 10,2 saat pengamatan kedua dibandingkan dengan pengamatan pertama. Pada pengamatan ketiga, persentase neutrofil kelompok kontrol meningkat sebanyak 3 namun peningkatan tersebut tidak bermakna (Gambar 1).

Pada seluruh kelompok perlakuan terlihat peningkatan yang bermakna saat pengamatan kedua dibandingkan pengamatan pertama. Peningkatan persentase neutrofil pada kelompok perlakuan 1 sebesar 12,5, kelompok perlakuan 2 sebesar 14,5, dan pada kelompok perlakuan 3 sebesar 16. Pada pengamatan ketiga terjadi penurunan yang bermakna pada persentase neutrofil seluruh kelompok perlakuan, yakni sebesar 8,8 pada kelompok perlakuan 1, sebesar 8,1 pada kelompok perlakuan 2, dan kelompok perlakuan 3 menunjukkan penurunan terbanyak sebesar 12 (Gambar 1). Terdapat penurunan pada kelompok perlakuan namun tidak pada kelompok kontrol saat pengamatan ketiga.

Berdasarkan grafik penelitian dengan data penelitian hasil neutrofil pada pengamatan ketiga didapatkan hasil bahwa terdapat penurunan yang dimulai dari terendah pada kelompok perlakuan 2 yaitu sebesar $8,1 \%$ kemudian penurunan pada kelompok. perlakuan 1 sebesar $8,8 \%$ dan penurunan paling banyak diberikan ditunjukkan 


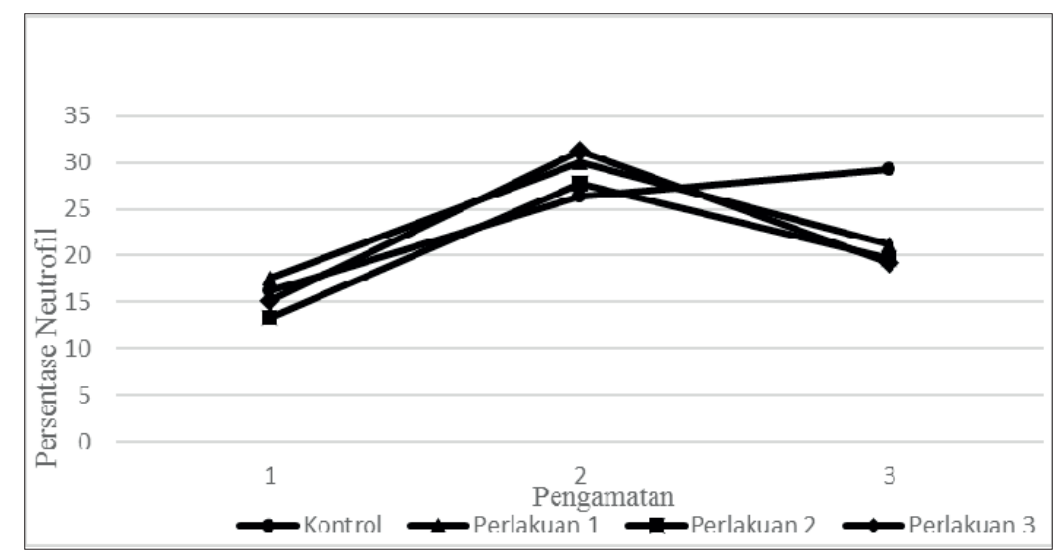

Gambar 1. Grafik Rerata Neutrofil Tiap Kelompok pada Tiap Pengamatan.

pada hasil kelompok perlakuan 3 yaitu sebesar $12 \%$. Perbedaan pada kelompok perlakuan 1 dan 2 hanya terpaut sedikit namun bermakna. Pemberian jus semangka sebanyak $1,5 \mathrm{ml}$ memberikan hasil lebih baik daripada pada pemberian $2,5 \mathrm{ml}$. Hal ini dapat dikarenakan pemberian sonde yang tidak mencapai lambung hewan coba ataupun dikarenakan faktor penyerapan dalam tubuh hewan coba yang kurang baik.

Hal ini sesuai dengan teori yang menyebutkan bahwa zat yang masuk ke dalam saluran pencernaan akan melalui esofagus di mana jika zat tersebut telah sampai pada daerah lambung maka spinchter pada ujung esofagus menuju lambung akan menutup untuk mencegah pengeluaran kembali zat tersebut. Jika terdapat kesalahan dalam pelepasan zat gizi pada esofagus, maka zat tidak terserap dan jika terdapat kesalahan pada spinchter maka zat tersebut akan kembali ke esofagus dari lambung. Hal ini yang menyebabkan zat tidak terserap sempurna oleh tubuh.

Penyerapan selanjutnya juga terjadi pada dinding usus halus di mana terdapat 3 cara penyerapan yaitu melalui proses difusi, osmosis, dan transpor aktif. Difusi merupakan proses masuknya zat gizi melalui membran yang berasal dari konsentrasi tinggi menuju konsentrasi rendah. Osmosis merupakan proses keluar dan masuknya cairan ke dalam sel untuk menjaga keseimbangan antara sel dengan lingkungan. Transpor aktif merupakan proses perpindahan senyawa melalui membran dengan bantuan carrier specific (Guyton dan Hall, 2007).

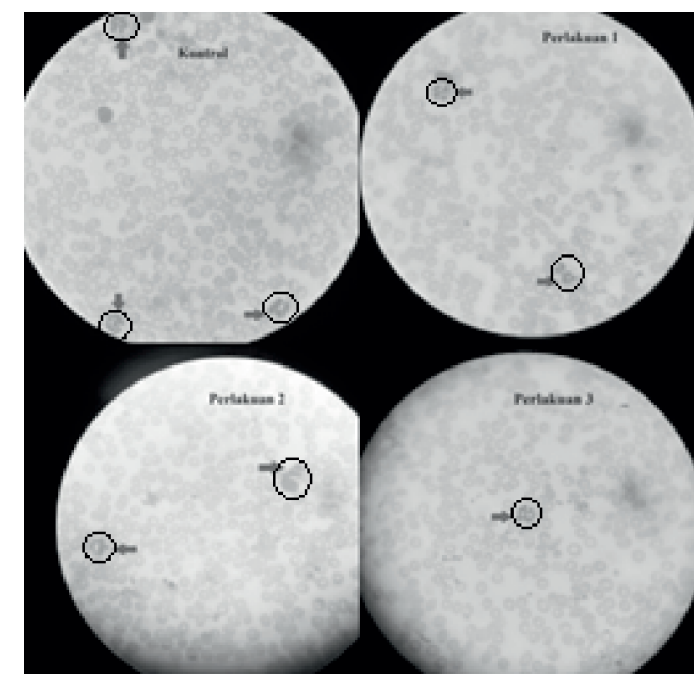

Gambar 2. Gambaran Mikroskopis Morfologi Neutrofil Tiap Kelompok pada Pengamatan Ketiga.

Gambaran mikroskopis yang ditunjukkan pada Gambar 2 memperlihatkan hasil gambaran morfologi neutrofil yang ditemukan pada tiap kelompok hewan coba saat pengamatan ketiga dengan pembesaran mikroskop 1000 kali. Pada kelompok kontrol ditemukan tiga buah neutrofil dalam satu lapangan pandang saat pengamatan ketiga. Jumlah tersebut menunjukkan gambaran lebih banyak jika dibandingkan dengan ketiga kelompok perlakuan.

Gambaran mikroskopis pada kelompok perlakuan 1 dan 2 ditemukan neutrofil sebanyak dua buah. Pada kelompok perlakuan 3 hanya ditemukan satu buah neutrofil dalam satu lapangan pandang. 
Tabel 4. Perbandingan Tiap Kelompok pada Pengamatan Ketiga

\begin{tabular}{lc}
\hline \multicolumn{1}{c}{ Perbandingan Kelompok } & Signifikan \\
\hline Kontrol - Perlakuan 1 & 0,021 \\
Kontrol - Perlakuan 2 & 0,007 \\
Kontrol - Perlakuan 3 & 0,005 \\
Perlakuan 1 - Perlakuan 2 & 0,649 \\
Perlakuan 1 - Perlakuan 3 & 0,545 \\
Perlakuan 2 - Perlakuan 3 & 0,879 \\
\hline
\end{tabular}

Hasil analisis One Way Anova menunjukkan adanya perbedaan yang bermakna antar kelompok $(p=0,017)$. Hasil uji perbandingan lanjut menggunakan Post hoc LSD menunjukkan bahwa kelompok kontrol berbeda nyata dengan perlakuan $1(\mathrm{p}=0,021)$, perlakuan $2(\mathrm{p}=0,007)$, dan perlakuan $3(\mathrm{p}=0,005)$. Tidak terdapat perbedaan antar masing-masing kelompok perlakuan $(\mathrm{p}>0,05)$.

Hasil uji One Way Anova dan Post hoc metode LSD pada hasil pengamatan ketiga menunjukkan bahwa terdapat perbedaan nilai neutrofil pada pengamatan ketiga antara kelompok kontrol dengan ketiga kelompok perlakuan namun tidak ada perbedaan antar masing-masing kelompok perlakuan. Hal ini menunjukkan bahwa pemberian jus semangka secara bermakna mampu menurunkan neutrofil dibandingkan dengan pemberian akuades. Hal ini sesuai dengan teori yang menyatakan bahwa semangka jenis Sugar Baby yang digunakan dalam penelitian mampu menjadi anti inflamasi pada keradangan yang terjadi akibat pemaparan asap rokok pada hewan coba. Hal ini dikarenakan semangka dengan jenis Sugar Baby memiliki kandungan anti inflamasi berupa likopen yang dapat bekerja secara efisien untuk menangkap radikal bebas yang terdapat pada asap rokok. Kondisi ini akan mengurangi kejadian inflamasi di dalam tubuh yang akan berdampak pada penurunan produksi sel inflamasi atau neutrofil pada sumsum tulang sehingga tidak akan didapatkan pula penurunan sel neutrofil pada darah tepi dan daerah yang mengalami inflamasi (Mateljan, 2007).

\section{KESIMPULAN DAN SARAN}

Terdapat penurunan rerata neutrofil pada ketiga kelompok perlakuan yang diberi jus semangka sebanyak 1,5 ml, 2,5 ml, dan 3,5 ml namun tidak pada kelompok kontrol dengan pemberian plasebo berupa akuades. Hal ini menunjukkan fungsi jus semangka sebagai anti inflamasi. Pemberian 3,5 $\mathrm{ml}$ jus semangka dapat berfungsi sebagai anti inflamasi lebih baik dibandingkan dengan pemberian jus semangka sebanyak $1,5 \mathrm{ml}$ dan 2,5 ml. Perokok pasif sebaiknya mengonsumsi jus semangka minimal sebanyak $84 \mathrm{ml}$ per hari (setara dengan $1,5 \mathrm{ml}$ pada hewan coba) sehingga dapat menurunkan risiko keradangan akibat paparan asap rokok.

\section{DAFTAR PUSTAKA}

Balitbangkes, RI. (2013). Laporan hasil Riset Kesehatan Dasar 2013. Indonesia.

Balitbangkes, RI. (2012). Global Adult Tobacco Survey: Indonesia report 2011. Indonesia.

Devaraj, S., Marthur, S.,Basu, A., Aung, H.H., Vasu, V.T., Meyers, S., Jialal, I. (2008). A dose-response study on the effects of purified lycopene supplementation on biomarkers of oxidative stress. Journal Nutrition, 27, 267273.

Dorland, W.A.N. (2002). Kamus kedokteran dorland terjemahan. Jakarta: EGC.

Eriksen, M.P., Mackay, J., Schluger, N., Gomeshtapeh F. I., Drope, J. (2015). The tobacco atlas. 5th Ed. USA: American Cancer Society, Inc.

Federer, W.T. (1967). Experimental design, theory, and application. New Delhi: Oxford and IBH.

Guyton, A.C., Hall, J.E. (2007). Textbook of medical physiology. Madrid: Elsevier, Inc.

Healey, J. (2011). Tobacco smoking. Australia: Spinney Press.

Hoffbrand, A.V., Pettit, J.E., Moss, P.A.H. (2005). Kapita selekta hematologi; 4th Ed. Jakarta: Kedokteran EGC.

Larson, D.E. (2003). Mayo clinic family health book: The ultimate home medical reference. $3 \mathrm{rd}$ Ed. USA: Mayo Clinic.

Lestariningrum, N.A., Karwur, F.F., Martosupono, M. (2012). Pengaruh vitamin E tokotrienol dan gabungannya dengan asam askorbat terhadap jenis leukosit tikus putih (Rattus norvegicus L.). Sains Medika, 4(1), 46-56.

Mateljan, G. (2007). The world's healthiest food. Canada: George Mateljan Foundation.

Naz, A., Butt, M.S., Sultan, M.T., Qayyum, M.M.N., Niaz, R.S. (2014). Watermelon lycopene and allied health claims. EXCLI Journal, 13, 650-666. 
Prihandari, R. (2016). Pengaruh pemberian jus semangka (Citrullus lanatus) sebagai anti inflamasi pada neutrofil tikus jantan galur wistar yang terpapar asap rokok (Skripsi tidak diterbitkan). Universitas Airlangga, Surabaya.

Rosalina, D. (2013). Infused water. Klaten: CV Sahabat.

Suryani, A. I. (2011). Efek jus tomat terhadap jumlah total leukosit dan neutrofil tikus wistar yang leukositosis setelah diberi paparan asap rokok. (Karya Tulis Ilmiah, Universitas Diponegoro Semarang). Diakses dari eprints. undip.ac.id/32799/1/Ade_Irma.pdf

Stavridis, J.C. (2008). Oxidation: The cornerstone of carcinogenesis. Greece: Springer.

Yuniharilmy, D. (2011). Efek vitamin E terhadap jumlah total leukosit dan neutrofil tikus wistar yang leukositosis setelah diberi paparan asap rokok (Karya Tulis Ilmiah, Universitas Diponegoro Semarang). Diakses dari eprints. undip.ac.id/32939/1/Dipa_Yuniharilmy.pdf. 